\title{
conomic Relations between Sweden and Romania during the Second World War
}

\section{Andreea Dahlquist}

Ph.D. student, Doctoral School of Valahia University of Târgoviște, e-mail: andreeaarch87(at)gmail.com

\begin{abstract}
The growth of Swedish-Romanian trade increased after Sweden opened its first diplomatic representation on Romanian soil in Galați (1851), Brăila (1852), Bucharest (1852), and Constanța (1880). In 1922, Sweden and Romania signed the first convention that regulated commerce. Later, in 1929, Romania took a loan of 30 million dollars from a Swedish concern in what proved to be a significant moment in the history of Swedish-Romanian economic relations. During the Second World War, both countries faced difficulties maintaining stable trade as a result of economic pressure from Germany and, eventually, the Soviet Union. Despite the challenges, Sweden succeeded in importing Romanian oil products, fodder, and grains - essential products for their economy - while Romania purchased Swedish agricultural machinery and other technologies. By the end of the war, several Swedish companies had established operations in Romania; among them, internationally recognized companies such as Swedish Matches, Kullager, Elektrolux, L.M. Ericsson,

\section{Rezumat}

Comerțul dintre Suedia și România s-a dezvoltat din ce în ce mai mult după ce Suedia și-a deschis reprezentanțele diplomatice la Galați (1851), Brăila (1852), București (1852) și Constanța (1880). In anul 1922 a fost semnată o convenție care reglementa comerțul suedezo-român. Un moment important în istoria relațiilor economice dintre cele două state l-a reprezentat împrumutul de 30 milioane de dolari pe care România l-a luat in anul 1929 de la un concern suedez. In timpul celui de-al Doilea Război Mondial, ambele țări au întâmpinat dificultăți în a menține un comerț stabil din cauza presiunii pe care Germania și apoi Uniunea Sovietică au exercitat-o asupra economiilor suedeze și românești. În pofida tuturor dificultăților, suedezii au reușit să importe din România produsele esențiale pentru consumul intern: petrol, produse furajere și cereale, în timp ce România a cumpărat și a transportat din Suedia, tehnologie și diverse utilaje agricole. La finalul războiului, mai multe companii suedeze își aveau sedii în România. Printre ele se numără companii cu istorie și recunoaștere internațională precum: Swedish Matches, Kullager, Elektrolux, L.M. Ericsson și Elektro-Invest.
\end{abstract} and Elektro-Invest.

Keywords: Second World War; Sweden; Romania; economy; trade

CC BY-SA License (https://creativecommons.org/licenses/by-sa/2.0)

Acknowledgements: This paper has been presented at the 11th international conference on Baltic and Nordic studies in Romania, Rethinking Europe in Scandinavia and the Baltic Sea Region, 28-29 May 2020. 
Swedish-Romanian relations only recently became a topical historiography subject and, consequently, many aspects of these bonds remain only partially researched. While several books and articles have been published detailing the diplomatic, political, social, cultural, and economic relations between Romania and the Nordic countries, the economic relations between Sweden and Romania during the Second World War have yet to be analyzed in-depth. The dynamics of SwedishRomanian economic ties during 1939-1945 are therefore worth investigating, not only in order to produce an accurate picture of how trade evolved during these years but to identify the challenges faced by these nations during this period. By doing so, it should be possible to determine which factors defined Romanian-Swedish economic ties, as well as the characteristics of this trade relationship as it evolved during the Second World War.

\section{A short history of Swedish-Romanian economic and trade relations before the Second World War}

Trade between Sweden and Romania accelerated following the opening of the first Swedish diplomatic representation on Romanian soil in Galați (1851), Brăila (1852), Bucharest (1852), and Constanța (1880). Viceconsulates from Galați and Bucharest were later raised to the rank of consulates, while two honorary consulates of Romania were established in Malmö and Gothenburg. At the beginning of the twentieth century, trade between the two countries was unremarkable. In 1910, for example, Sweden exported products worth only 71,698 Swedish crowns (358 186 EUR) ${ }^{1}$ to Romania ${ }^{2}$.

\footnotetext{
${ }^{1}$ To obtain the value in Euros I first used the converter used by the Statistiska centralbyråns (SCB) and recommended by the Swedish National Bank (http://www.sverigeisiffror.scb.se/hitta-statistik/sverige-i-siffror/prisomraknaren/) to calculate the inflation for Swedish crowns. I calculated the inquiry on 2019 inflation. After that, I used the 2019 exchange rate published by the Swedish National Bank (https://www.riksbank.se/sv/statistik/sok-rantor--valutakurser/manadsgenomsnittvalutakurser $/ \mathrm{y}=2019 \& \mathrm{~m}=12 \& \mathrm{~s}=$ Comma\&f$=\mathrm{m}$.) for converting the Swedish crowns to Euros. ${ }^{2}$ Aftonbladet, July $9^{\text {th }} 1912,14$.
} 
Romania, in need of foreign capital in order to develop its industry and agriculture, managed to attract foreign investors via the 'open door policy' implemented by the National Peasants' Party in 1928. Under these favourable conditions, Swedish investors seized the opportunity to invest capital in the Romanian oil industry ${ }^{3}$.

In 1922, Sweden and Romania signed a convention that regulated trade. Following this agreement, imports from Romania increased considerably and Sweden failed to maintain balance; Swedish exports to Romania did not reach even half the amount of imports from the same nation 4 .

While Sweden exhibited a particular interest in fodder and petroleum products, Romania attempted to sell a new product to the Swedish market: fruits. However, Romanians needed to adapt and provide high-quality fruits in order to compete with Australian, Austrian, and American produce 5 .

A significant moment in the history of Romanian-Swedish economic relations was the loan of 30 million dollars, which the Kreuger Group 6 granted to Romania in $1929^{7}$. A substantial portion of the loan came from 'Svenska Tändsticks $\mathrm{AB}^{` s}$ (STAB), which, in return, claimed several

${ }^{3}$ Gheorghe Buzatu, O istorie a petrolului românesc (Iași: Casa Editorială Demiurg, 2009), 33.

${ }^{4}$ During 1938, Sweden imported from Romania products worth 5.9 million Swedish crowns (16 738230 EUR), and in 1939, the imports almost reached 6.8 million Swedish crowns (18 724122 EUR). During this time, Sweden exported products worth 3.4 and 1.2 million Swedish crowns (9645760 EUR and 3304257 EUR) to Romania. Sveriges Riksarkivet, Utrikesdepartementet, [The National Archive of Sweden, Ministry of Foreign Affairs, hereafter Riksarkivet, UD], HP 2803, Rumänien, vol. VII, April-December 1941, unpaged.

${ }^{5}$ Arhivele Diplomatice ale Ministerului Afacerilor Externe al României [The Diplomatic Archives of the Romanian Foreign Ministry, hereafter AMAE], fund 71/Suedia, 1928-1944, vol. 21, 56.

${ }^{6}$ The Swedish industrialist Ivar Kreuger founded Kreuger Group in 1911. This concern included 200 companies. From their income, Kreuger Group lent to several countries, including Romania. In exchange for money, the Swedes requested to monopolize several industrial sectors in the country that made the loan. Klarin E., 'Svenska tändstickbolaget och Kreuger-koncernen ' in Svenska Dagbladets Arsbok, ed. E. Rudberg, E. Hellblom (Stockholm: Åhlén \& Åkerlunds Boktryckery, 1928), 280-281.

${ }^{7}$ Riksarkivet, UD, HP 2803, Rumänien, vol. VII, April-December 1941, unpaged.

${ }^{8}$ Svenska Tändsticks $A B$, or Swedish Match $A B$ is a Swedish company founded by Ivar Kreuger in 1917, in Jönköping. Ten years later, STAB became the world's leader in match production. STAB reached its peak in 1930. At that time, STAB owned match companies in 
concessions. Romania, however, suffering as a result of territorial losses in 1940, was unable to repay the loan in due time9.

Between 1936-1937, Swedish-Romanian trade flourished and brought 275 million lei (102 $\left.037889972 \mathrm{EUR}^{10}\right)$ to the Romanian national budget $^{11}$. By 1938, however, Sweden had lost interest in Romanian oil, instead of relying on Mexican imports. Demand for grain similarly decreased due to an abundant Swedish harvest that same year ${ }^{12}$. Trade between the two countries was also negatively affected by Romanian legislation. Kamrer Warnqvist, a Swedish businessman with ventures in Romania, considered the problem to be a lack of organization within Romanian economic and administrative structures, which still bore the patterns of oriental practices. Warnqvist believed that Swedish-Romanian trade needed some changes; in particular, he emphasized an economic contract that should detail payment methods and instructions for export ${ }^{13}$.

As a result of Romanian political instability, 'Helsingborgs Gummifabriks AB` had difficulties in exporting its products to Romania. In early 1938, Sweden was the leading exporter of rubber products in Romania. 'Helsingborgs Gummifabriks $A B$ ' exported shoes, galoshes, boots, and rubber boots worth 16944000 lei (646641 EUR) to Romania, exceeding the amount sold to countries like Germany, Austria, and Czechoslovakia ${ }^{14}$. Despite this success, 'Helsingborgs Gummifabriks' failed to appear on Romanian rubber supplier documents later on.

33 countries and controlled $60 \%$ of the world's match production. The success started to fade after the death of Ivar Kreuger in 1932. (For a complete overview, see: Svenska Tändsticks $\mathrm{AB}$ at https://www.swedishmatch.com/Our-company/Companyhistory/Svenska-Tandsticks-AB/).

9Romania's debt to Sweden was fully paid only in 2003 during Adian Nastase's administration. The debt estimation was 120 million dollars.

${ }^{10}$ I calculated Leu's inflation using the dates from Mircea Ciumara, Constantin Ciutacu, Inflația în România. Modelarea fenomenului inflaționist (București: Editura Expert, 2004), 58-87. After I estimated the inflation, I used the official exchange rate from the Romanian National Bank, https://www.cursbnr.ro/convertor-valutar, to convert Lei into Euros. The inquiry is on 2020 inflation.

${ }^{11}$ Riksarkivet, UD, HP 2802, Rumänien, vol. VI, May 1932 - Mars 1941, unpaged.

${ }^{12}$ Riksarkivet, UD, H 1277, Rumänien, unpaged.

${ }^{13}$ Riksarkivet, UD, HP 2802, Rumänien, vol. VI, May-1932 - Mars 1941.

${ }^{14}$ Riksarkivet, UD, H 1264, unpaged. 
Tannin provider 'Garvämnes AB Weibull' suffered a similar fate, this time as a result of Swedish governmental decisions. During the interwar period, 'Garvämnes AB Weibull' saw an increase in the amount of tannin exported to Romania (see Table 1). Towards the end of 1939, however, Sweden banned the export of tannin products - a decision that proved detrimental to the company's economy ${ }^{15}$.

Table 1: The tannin quantity exported by Garvämnes A.B Weibull during 1936-1939

\begin{tabular}{|r|c|}
\hline Year & $\begin{array}{c}\text { Tannin quantity } \\
\text { (tons) }\end{array}$ \\
\hline $\mathbf{1 9 3 6}$ & 12 \\
\hline $\mathbf{1 9 3 7}$ & 59 \\
\hline $\mathbf{1 9 3 8}$ & 111 \\
\hline $\mathbf{1 9 3 9}$ & 136 \\
\hline
\end{tabular}

Source: Riksarkivet, UD, HP 2805, Rumänien, Vol. XIII, April - May 1943.

By quoting these values in a letter sent to the Swedish Trade Commission, 'Garvämnes $\mathrm{AB}$ Weibull' attempted to demonstrate the profitability of tannin exports and request permission to continue trade with Romania ${ }^{16}$.

Despite the circumstances, companies such as 'Svenska Tändsticks $A B `$ were still interested in increasing their exports to Romania.

\section{A history of economic and commercial relations between Sweden and Romania during the Second World War}

Once the Second World War had begun, trade between Sweden and Romania was affected by the evolution of hostilities on the Eastern front. Due to the conflict, the price of petroleum products increased significantly, and trade on the Danube was blocked. Romania did not have the benefit of a developed railway network in order to sustain the transportation of large

\footnotetext{
${ }^{15}$ Riksarkivet, UD, HP 2805, Rumänien, vol. XIII, April - May 1943, unpaged. ${ }^{16}$ Ibid.
} 
quantities of crude oil. In addition to this, the Romanian government began claiming compensation for the export of fodder.

Meanwhile, the situation in Sweden became precarious at the beginning of the war as a result of the struggle to stay neutral and yet maintain its economic relations with both neutral states and belligerents. Germany, in disagreement with this approach, attempted to prevent Sweden from trading with England via a number of methods, including water mining and torpedoing neutral vessels off the Swedish coast ${ }^{17}$. Moreover, Germany demanded that Sweden deliver iron ore and other products that would support the German war economy.

The winter of 1939-1940 was long and bitter, causing significant damage to Romanian agriculture. Romanian authorities, therefore, decided to ban wheat export in favour of prioritizing domestic consumption and army supplies ${ }^{18}$. This decision affected Sweden, as wheat was one of the main products imported from Romania. Throughout 1940, Romania exported only 1247612 tons of grain, of which Sweden succeeded in buying 47645 tons $^{19}$. Germany, Italy, and England were the countries to which Romania exported most grain that year.

During February 1940, Romania adopted a law which resulted in extra custom duties on a number of Swedish imports ${ }^{20}$. Romanian authorities justified this decision on the grounds that the state needed supplementary finances in order to overcome the economic crises that hit the country during the interwar period. Once the Second World War broke out, the price of grains and oil had increased considerably; Romanian products, therefore, became among the most expensive in Europe.

Significant challenges in Swedish-Romanian trade arose following both the issuing of transport licenses and Romania's inability to pay for products bought from Sweden. These problems emerged as a result of a lack of a signed trade contract, in addition to a rudimentary and nonfunctional payment system that often relied on using compensation to cover acquisitions. One Swedish company that faced difficulties in

\footnotetext{
${ }^{17}$ AMAE, Fund 71/Suedia, 1928-1944, vol. 21, 262.

${ }^{18}$ Riksarkivet, UD, H 867, Rumänien 1920-1950, vol I, unpaged.

${ }^{19}$ Riksarkivet, UD, HP 2802, Rumänien, vol. VI, May 1932 - Mars 1941, unpaged.

${ }^{20}$ Riksarkivet, UD, H 610 Tulltariffer, exporttullar 1932-1951, vol. II, unpaged.
} 
obtaining transport sheets was 'AGA-Baltic Radio AB', which was licensed to export radio equipment to Romania ${ }^{21}$. 'SKF $A B$ ' also encountered significant problems in obtaining export licenses and recovering its debts ${ }^{22}$. Towards the end of 1940, 'SKF AB' shipped bearings worth 76.3 million lei (2 417805 EUR) to Romania and received only 22.3 million lei (706 645 EUR) due to the Swedish Foreign Ministry's intervention ${ }^{23}$.

In March 1940, 'BA Hjorth \& Co'$^{24}$ sent an official letter to the Swedish Foreign Ministry, pointing out the necessity of a trade contract in order to regulate the commercial ties between Sweden and Romania, particularly as the company's exports to this country had stagnated..$^{25}$

During the first half of 1940, Romanian and Swedish officials conducted intense negotiations in Berlin with the goal of convincing the German authorities to allow the transit of oil tanker trains from Romania to Sweden. While discussions did not go as expected, eventually, all three parties signed an agreement. Accordingly, Sweden was allowed to pass 4 500 tons of oil products per month through Germany from Romania ${ }^{26}$. There was, however, a condition: the Swedish oil tankers were not to disturb Germany's usual train circulation. These products would reach the Stettin harbor before being transported over the Baltic Sea to Trelleborg by the oil tanker 'Carina' 27.

\footnotetext{
${ }^{21}$ Riksarkivet, UD, HP 2802, Rumänien, vol. VI, May 1932 - Mars 1941, unpaged.

${ }^{22} \mathrm{SKF} \mathrm{AB}$ - Svenska Kullagerfabriken is an industrial company that produces different types of bearings. It was established in 1907, in Gothenburg. The company grew at record speed and became Gothenburg's first multinational corporation. From the mid-1930s, the group expanded sharply. It opened 13 factories - four in Sweden, three in Germany, two in France, two in the United States, andone in Great Britain and Czechoslovakia. 'AB Svenska Kullagerfabriken (1907-)',https://sok.riksarkivet.se/agent/ OWJTCmDHI4YSYu0IfuAJY0, accessed 08.08. 2019.

${ }^{23}$ Riksarkivet, UD, HP 2802, Rumänien, vol. VI, May 1932 - Mars 1941, unpaged.

${ }^{24}$ B.A Hjorth\& Co. was initially a tool and machinery shop, opened in 1889 in Stockholm by businessman Berndt August Hjort. In 1916 he bought the shares of the "Enköpings Mekaniska Verkstad", a workshop belonging to the inventor Johan Petter Johansson (known for inventing the adjustable wrench for pipes) and transformed the shop into a renowned company. In 1954 the company changed its name in AB. Bahco. Rune Kjellander, 'Berndt A Hjorth', https://sok.riksarkivet.se/sbl/Presentation.aspx?id=13649, accessed 08.08.2019.

${ }^{25}$ Riksarkivet, UD, HP 2802, Rumänien, vol. VI, May 1932 - Mars 1941, unpaged.

${ }^{26}$ Riksarkivet, UD, H 1277, Rumänien,unpaged.

${ }^{27}$ Ibid.
} 
While succeeding in remaining neutral, Sweden was unable to escape the threat of the economic crisis in the form of inflation and rising unemployment. In order to prevent economic collapse, the Swedish government proposed several measures: concentrated labour in industries that increased domestic production in order to satisfy demand, rationing, and additional tax for extra benefits.

Meanwhile, the Swedish Company 'Separator $A B^{\prime 28}$ succeeded in obtaining permission to export milk separators worth 26799 Swedish crowns (64 998 EUR) to Romania. This was paid by Romania under an installment plan ${ }^{29}$.

The balance of 1940 showed that Sweden imported Romanian goods worth 8201471 Swedish crowns (19891883 EUR) and paid the amount of 7956858 Swedish crowns (19347 105 EUR) for the following products $^{30}$ :

Table 2: Romanian products imported by Sweden in 1940

\begin{tabular}{|l|c|c|}
\hline \multicolumn{1}{|c|}{ Product } & Value in SEK 1940 & $\begin{array}{c}\text { Estimated value in } \\
\text { EUR 2019 }\end{array}$ \\
\hline $\begin{array}{l}\text { Kerosene, as well as other } \\
\text { refined fuels }\end{array}$ & 2436655 & 5909874 \\
\hline Oil cakes and lentil & 2421656 & 5873495 \\
\hline Fodder & 1045867 & 2536650 \\
\hline Wheat bran & 751469 & 1822616 \\
\hline Peas & 359223 & 871261 \\
\hline Corn & 273702 & 663838 \\
\hline Acetone, butanone & 226288 & 548840 \\
\hline Lubricants: transformer oil & 178290 & 432425 \\
\hline
\end{tabular}

\footnotetext{
${ }^{28}$ Separator AB company (later named Alfa Laval) was founded in 1883 in Stockholm by Gustaf de Laval and Oscar Lamm Jr. The two engineers invented the centrifugal machine used in the dairy industry and known as the De Lavel separator. Nationalencyklopedin, 'AB Separator', $\quad$ https://www.ne.se/uppslagsverk/encyklopedi/1\%C3\%A5ng/ab-separator, accessed 08.08.2019.

${ }^{29}$ On May 24 $4^{\text {th }}$, Romania paid 17000 Swedish crowns (41 232 EUR) and should pay the remaining 9000 Swedish crowns (21 829 EUR) thereafter.

${ }^{30}$ Riksarkivet, UD, HP 2803, Rumänien, vol. VII, April - December 1941, unpaged.
} 


\begin{tabular}{|l|r|r|}
\hline Gasoline & 157178 & 381220 \\
\hline Timber & 126530 & 306886 \\
\hline & Total: 7 956 858 & Total: 19 347 105 \\
\hline
\end{tabular}

Source: Riksarkivet, UD, HP 2803, Rumänien, Vol. VII, April December 1941.

Romania, on the other hand, imported goods valued at only 1873 881 Swedish crowns (4 544919 EUR) from Sweden. Romanian authorities could pay the amount of 1372311 Swedish crowns (6 656818 EUR) for the following products:

Table 3: Swedish products exported to Romania in 1940

\begin{tabular}{|c|c|c|}
\hline Product & Value in SEK 1940 & $\begin{array}{c}\text { Estimated value in } \\
\text { EUR 2019 }\end{array}$ \\
\hline $\begin{array}{c}\text { Bearings and } \\
\text { bearing segments }\end{array}$ & 409573 & 993380 \\
\hline Artillery parts & 337396 & 818322 \\
\hline $\begin{array}{c}\text { Ferrosilicon and } \\
\text { silicon }\end{array}$ & 252045 & 611311 \\
\hline Slide bearing & 195236 & 473526 \\
\hline Centrifuges & 71506 & 173431 \\
\hline Steam turbines & 58165 & 141074 \\
\hline $\begin{array}{c}\text { Chemical } \\
\text { products }\end{array}$ & 48390 & 117365 \\
\hline
\end{tabular}

Source: Riksarkivet, UD, HP 2803, Rumänien, vol. VII, April December 1941

Despite continuing to stay neutral, the Swedish economy suffered due to unpredictable war developments. Sweden, having enjoyed a history of good relations with the USA, possessed an estimated wealth of 222 
million dollars (2 261447075 EUR $^{31}$ ) in the American banks. Meanwhile, American capital invested in Sweden amounted to 25 million dollars (254 667463 EUR) ${ }^{32}$. During the war, the US allowed Sweden to recover its money; however, it asserted that Swedish ships belonged to the belligerents. This meant that Sweden was required to pay significantly higher insurance fees for the vessels to sail in US waters.

Following the Soviet Union's attack on Finland, the harbour of Petsamo was blocked, and sailing on the Baltic Sea became almost impossible. This led to the rupture of economic ties between Sweden and East Asia ${ }^{33}$, a development that had marked effects on the Swedish economy; industries struggled to achieve access to raw materials, while coal, coke, and grain reserves depleted.

After the German invasion of Denmark and Norway, Sweden lost access to the transatlantic trade $-70 \%$ of the total Swedish commerce ${ }^{34}$. This critical situation compelled authorities in Stockholm to find new markets and strengthen trade with these countries. Sweden consolidated trade in the Baltic Sea through three measures: forming a treaty with the USSR on September 1 19t, 1940; becoming an important trading partner to Germany; finally, reorganizing its commerce with Italy, to which it began to export timber and machinery ${ }^{35}$. Sweden also attempted to achieve a means of importing more Romanian grains by offering different products as compensation. However, Romania requested large quantities of products that Sweden was unable to deliver ${ }^{36}$. For example, for 400 wagons of oil residues, the Romanian authorities requested 10 tons of ferrovanadium, 30 tons of ferromolybdenum, 400 tons of ferrosilicon, and 100 tons of

\footnotetext{
31 To obtain the value in Euros, first, I used the dates published by Jan Bohlin in his chapter From appreciation to depreciation - the exchange rates of the Swedish krona 1913-2008 accessed on https://www.riksbank.se/en-gb/about-the-riksbank/the-tasks-of-the-

riksbank/research/historical-monetary-statistics-of-sweden/volume-i-exchange-rates-pricesand-wages-1277-2008/ to exchange Dollars to Swedish crowns. After that, I calculated the inflation for Swedish crowns using the SCB converter. Finally, I used the 2019 exchange rate from the Swedish National Bank for converting the Swedish crowns into Euro.

${ }^{32} \mathrm{AMAE}$, Fund 64/Suedia, vol. 4, 355.

${ }^{33}$ Ibid., 400-401.

${ }^{34}$ AMAE, Fund 71/Suedia, 1928-1944, vol. 21, 336.

${ }^{35}$ AMAE, Fund 64/Suedia, vol 4, 258.

${ }^{36}$ Riksarkivet, UD, HP 2802, Rumänien, vol. VI, May 1932 - Mars 1941, unpaged.
} 
ferromanganese ${ }^{37}$. Following intense negotiations, both governments agreed that Romania would deliver 2000 tons of grain, and Sweden would reciprocate with 1000 tons of ferrosilicon ${ }^{38}$.

Meanwhile, Sweden bought 20000 liters of benzine and 10000 liters of kerosene from Romania via a German company ${ }^{39}$. Sweden carried out the freight with 680 tanks provided by the Swedish railway company, each tank able to carry a capacity of 20 tons $^{40}$.

Product transportation from Romania to Sweden became increasingly problematic. Romania lacked a sufficient number of tank trains in order to carry the entire quantity from Ploiesti to Stettin. Additionally, the fact that Romanian rail traffic was operating under the monopoly of the army hampered the export even more ${ }^{41}$. The alternative was for Romania to deliver the oil products using tanker barges on the Danubian section between Giurgiu and the port of Bratislava. There the cargo was loaded onto trains and transported to the port of Stettin. The oil company 'Creditul Minier' purchased ten barges and promised to allocate six for the export to Northern Europe. Meanwhile, Sweden found another way to import goods of Romanian origin by buying them from Germany, Hungary, Slovakia ${ }^{42}$, or Portugal ${ }^{43}$.

In the autumn of 1941, representatives of the Romanian company 'Scarom' and the Swedish authorities negotiated a new trade agreement based on compensation. Thus, the Romanians requested 20000 barrels of herring ${ }^{44}$ in exchange for 2000 tons of industrial lubricants: 500 tons of paraffin, 1500 tons of petroleum jelly, and 1000 tons of yellow peas ${ }^{45}$. The

\footnotetext{
${ }^{37}$ AMAE, Fund 71/Suedia, vol. 22, 371-374.

${ }^{38}$ Riksarkivet, UD, HP 2803, vol. VII, April - December 1941, unpaged.

${ }^{39} \mathrm{Ibid}$.

${ }^{40}$ Riksarkivet, UD, H 1277, Rumänien, unpaged.

${ }^{41}$ Riksarkivet, UD, HP 2803, Rumänien, vol. VII, April - December 1941, unpaged.

${ }^{42} \mathrm{Ibid}$. According to the report of July $10^{\text {th }} 1941$, Sweden imported products of Romanian origin worth 2889000 Swedish crowns (6 175112 EUR) from Germany, Romanian products worth 28000 Swedish crowns (59 849 EUR) from Hungary and Romanian products worth 34000 Swedish crowns (72 674 EUR) from Slovakia during the period January-May 1941.

${ }^{43}$ Ibid., According to the report of August 25 $5^{\text {th }} 1941$, Sweden imported products of Romanian origin worth 1950 Swedish crowns (4 168 EUR) from Portugal.

${ }^{44} \mathrm{Ibid}$. Of the 20000 barrels of herring, 12000 contained herring from Norway.

${ }^{45}$ Ibid.
} 
Swedish authorities set a condition: to deliver the fish after the Romanian goods arrived in the Baltic Sea ports. The problem was that the Romanian authorities were in no hurry to release the transportation permits, which caused panic among Swedish exporters, who feared that the herring could get damaged and lose value ${ }^{46}$.

Sweden also intended to export furfural, a substance used in the aeronautical industry, to Romania. The negotiations failed, however, as no Romanian goods could compensate for the value of furfural. The failure demonstrated once again that the compensation trade system was archaic and did not bring profit for either country ${ }^{47}$. In order to revive the SwedishRomanian trade, a new commercial contract would be needed to regulate payment methods. Compensation trade was inefficient, and Sweden disagreed with the clearing system due to the geographical distance between the countries. It would also be necessary for Romania to send a commercial attaché to Stockholm, who would be responsible for traderelated questions ${ }^{48}$. The Romanian authorities granted the request promptly and appointed Minister Grigore Gheață as commercial attaché in Stockholm ${ }^{49}$.

Another complicated business venture was that of the Romanian authorities and the Swedish arms manufacturer 'AB Bofors ${ }^{50}$. Romania ordered weapons from 'Bofors' in 1938-1939; however, the transport was delayed - Swedish authorities were no longer interested in delivering the armaments after war broke out as they were unwilling to supply weapons to a belligerent state ${ }^{51}$.

Although 1941 was an unfortunate year for Swedish-Romanian trade, Sweden remained the largest Scandinavian direct importer of feed

\footnotetext{
${ }^{46}$ Ibid.

${ }^{47}$ AMAE, Fund 71/Suedia, 1928-1944, vol. 21, 364.

${ }^{48}$ Riksarkivet, UD, HP 2803, Rumänien, vol. VII, April - December 1941, unpaged. ${ }^{49}$ Ibid.

${ }^{50} \mathrm{AB}$ Bofors was an industrial armaments company founded in 1646. Alfred Nobel was the principal owner of the company from 1894 until his death in 1896. The best-known 'Bofors' product used during World War II was the $40 \mathrm{~mm}$ anti-aircraft gun. Theodor Westrin, ed., Nordisk familjebok, (Stockholm: Nordisk Familjebok Tryckeri, 1922), 711.

${ }^{51}$ AMAE, Fund 71/Suedia, 1928-1944, vol. 21, 365.
} 
from Romania ${ }^{52}$ (although Denmark bought larger quantities of Romanian fodder, it was imported indirectly through German trading houses ${ }^{53}$ ). Despite this, Albert Walldén, Romanian consul in Malmö, sent an official letter to the Swedish envoy and plenipotentiary minister in Bucharest, Patrik Reuterswärd, complaining that the price of the Romanian fodder was too high - even higher than the price Sweden paid to import the same products from Argentina ${ }^{54}$. Walldén also noted that Sweden always paid for purchases from Romania, whereas the Romanian government often lacked money to cover imports from Sweden and would request more compensation. Walldén, a fierce opponent of compensation trade, would openly criticize this practice on several occasions ${ }^{55}$.

Another challenge for the Swedish-Romanian fodder trade was the German monopoly. Germany wanted to import high quantities of fodder from Romania, even if it was not necessary. The plan was to buy forage and to sell it to other countries. The Nordic states had maintained their position as the leading importers of Romanian fodder, and Sweden did not want to lose this status. Equally, Romania was more interested in exporting grains to Sweden than to other countries as Sweden was, at that moment, the only state except for Switzerland that could pay with free currency ${ }^{56}$.

Germany's pressure on the Romanian economy caused a complete trade freeze between Sweden and Romania in the first half of 1942. The general secretary of the Romanian Finance Ministry, Mihai Răzmeriță, traveled to Stockholm to inform the Swedish authorities about Berlin's decision regarding Romanian-Swedish trade. According to Răzmeriță, Germany recommended Romania to stop trading with Sweden because the country had declared itself neutral; therefore, Swedish demands should not be taken into account ${ }^{57}$. Moreover, Germany assured Romanian authorities that it could export the same number of tractors, machine tools, and other

\footnotetext{
${ }^{52}$ Riksarkivet, UD, HP 2803, Rumänien, vol. VII, April - December 1941, unpaged.

${ }^{53}$ Oana Popescu, România și Danemarca în prima jumătate a secolului XX, (Târgoviște: Editura Cetatea de Scaun, 2010), 102.

${ }^{54}$ Riksarkivet, UD, HP 2803, Rumänien, vol. VII, April - December 1941, unpaged.

55 Ibid.

${ }^{56}$ Riksarkivet, UD, HP 2803, Rumänien, vol. VIII, January - May 1942, unpaged.

${ }^{57}$ Ibid.
} 
machinery that Sweden would deliver. Germany also demanded that Romania limit the selling of agricultural products and stop exporting petroleum to other countries, with the exception of the Axis states.

Another decision that affected Swedish-Romanian trade was the royal decree published on December $18^{\text {th }}, 1941$. This law put the grain and fodder trade under the Romanian state monopoly. Consequently, companies that principally sold these products were forced to close their businesses ${ }^{58}$. This decision affected Swedish interests as tons of purchased grains were stranded in the Romanian harbours.

In addition to these problems, German practices provided more obstacles. Although Germany agreed with Deputy Prime Minister Mihai Antonescu not to interfere in commerce between Romania and Sweden, German authorities did not issue transport licenses. This decision blocked the export of several freight trains, despite the Swedish state having paid for the merchandise. A serious incident occurred with the transportation delay of 30 tanks containing oil for axles and sliding guides that Romania planned to deliver to Sweden in exchange for tungsten ${ }^{59}$. The situation became so critical that Mihai Antonescu asked Ion Marinescu, the National Economy Minister, to talk with the German ambassador in Bucharest, Manfred von Killinger, in an attempt to resolve the situation.

Given that Romania did not have enough freight trains to export its products, Sweden was required to send empty sets. This maneuver took a significant amount of time due to Germany's decision to limit train transit from Sweden to Romania ${ }^{60}$.

Although rail transport proved difficult, navigation on the Danube was blocked entirely. Barges loaded with purchased grains intended for Sweden did not receive transport licenses. The delay led to increased costs due to additional parking fees ${ }^{61}$. Added to these costs was the double price that Germany demanded to approve the transit of goods on its territory ${ }^{62}$.

\footnotetext{
58Riksarkivet, UD, H 867, Skörden, spannmålshandeln, Rumänien, 1920-1950, vol I, unpaged.

${ }^{59}$ Riksarkivet, UD, HP 2803, Rumänien, vol. VIII, January - Mai 1942, unpaged.

${ }^{60}$ Ibid.

${ }^{61}$ Ibid.

${ }^{62}$ Riksarkivet, UD, HP 2803, Rumänien, vol. IX June - August 1942, unpaged.
} 
Meanwhile, Romania tried once more to buy Swedish weapons; however, the managers of 'Bofors' replied that the company could not honor new orders. The Romanian navy was in great need of Swedish war material, and Bofors' refusal to export it led to strained economic and diplomatic relations between Sweden and Romania. The commercial attaché in Stockholm, Grigore Gheață, considered the possibility of purchasing Swedish weapons through Finland. The plan was for Finland to buy the requested weapons, which would then be sold to Romania ${ }^{63}$. However, Victor Brabețianu, the Romanian plenipotentiary minister to Stockholm, proposed a controversial method that could only function in collaboration with Germany. Thus, Romania would sell the much-desired mineral oil to Sweden. However, during the transit through Germany, the authorities would stop the tanker trains without reason. Once the Stockholm authorities inquired about the delivery, they would receive the response that the merchandise would not reach its destination until Sweden issued transportation licenses for the war material that was to arrive in Romania ${ }^{64}$.

Despite these circumstances, Romania succeeded in importing goods for 37991155 lei (957 864 EUR) from Sweden in the first quarter of 1942 and exporting products in return for 256923420 lei (6 477764 EUR) ${ }^{65}$. However, in May 1942, the situation worsened as Romanian authorities had not issued transport licenses for weeks. The General Consul Albert Walldén bought high quantities of fodder, but he could not move the goods from the Romanian harbors. Walldén asked Minister Hägglöf for help, who contacted the Romanian authorities and requested an explanation. The answer was that Romania would not approve new transport licenses before the two countries signed a new trade agreement ${ }^{66}$.

In addition to this, Germany announced that it would no longer permit the transit of new petroleum shipments from Romania to Sweden ${ }^{67}$. Nevertheless, Sweden was still owed 1335 tons of industrial oils, 300 tons

\footnotetext{
${ }^{63} \mathrm{AMAE}$, Fund 71/Suedia, vol. 6, 331.

${ }^{64}$ Ibid., 319.

${ }^{65}$ AMAE, Fund 71/Suedia, vol. 22, 371-374.

${ }^{66}$ Riksarkivet, UD, HP 2803, Rumänien, vol. VIII, January - May 1942, unpaged.

${ }^{67}$ Ibid.
} 
of paraffin, and 150 tons of Vaseline from previous orders. Another 200 tons of industrial lubricants were in Bratislava, and 150 tons of paraffin were on the way to Sweden ${ }^{68}$. These quantities were from a countervailing trade, according to which Romania would export 2000 tons of industrial oils, 500 tons of paraffin, and 150 tons of petroleum jelly in exchange for 6 460 barrels of herring.

Neither was Germany willing to issue transport licenses for fodder before Romania delivered its quota. Blocking transportation to Sweden compelled many Romanian companies to sell their products to other countries, such as Finland and Switzerland ${ }^{69}$.

Trade between Sweden and Romania seemed impossible at this point due to Romanian and German authorities blocking transportation and pressing Sweden for more taxes. Not only was Germany asking for prohibitively high prices for transit, but Bucharest's Minister of the National Economy was requiring the Swedish authorities to pay higher fees than those stipulated in the trade agreements ${ }^{70}$.

At the end of summer 1942, Romania once again raised customs duties. The fee for a ton of corn was 10000 lei (250 EUR), while for a ton of alfalfa and clover seeds, the price was 20000 lei $^{71}$ (500 EUR). Germany continued to reject transport licenses and confiscated barges with cereals that were due to arrive in Sweden ${ }^{72}$.

Although it seemed that trade between Romania and Sweden was almost impossible, the desire to maintain economic relations remained for both countries. Therefore, from September $25^{\text {th }}$ to October $12^{\text {th }}, 1942$, a Swedish delegation that included Waldén and the first secretary of the Swedish Ministry of Foreign Affairs, K. A. Belfrage, traveled to Bucharest. There they negotiated with the Romanian state for the redemption of debts that Romanian banks had to various Swedish companies ${ }^{73}$.

\footnotetext{
${ }^{68}$ Ibid.

${ }^{69} \mathrm{Ibid}$. 'Granosa SAR', a Romanian company from Bucharest, sold 800 tons of peas to Finland and 1500 tons of peas to Switzerland.

${ }^{70}$ Riksarkivet, UD, HP 2803, Rumänien, vol. IX June - August 1942, unpaged.

${ }^{71}$ Riksarkivet, UD, H 610, Tulltariffer, exporttullar, 1932-1951, vol. II, unpaged.

${ }^{72}$ Riksarkivet, UD, HP 2804, vol. X, September - November 1942, unpaged.

${ }^{73}$ Ibid.
} 
The report ${ }^{74}$ that Belfrage wrote during his stay in Bucharest detailed the chaos he found at the Ministry of National Economy. In August 1942, Ion N. Fințescu had become the new Economy Minister. He failed in reforming the Ministry as he was unable to find competent people to fill the available positions. At that time, the whole institution was in the process of reformation. The change aimed to reduce the pressure on the Ministry of Economy by transferring more tasks to the Department of State Undersecretary for Trade, Industry and Mining. The entire Romanian administrative system was deemed too disorganized for the Swedish diplomats.

During the negotiations, Sweden claimed that Romania charged excessively high prices for its products. The grains were especially expensive as Romania had suffered a long and hard winter followed by a dry summer; however, prices remained high for perishable products, such as eggs. Sweden was unwilling to pay more than four Swedish crowns for a one-kilo egg and so opted to purchase it from Switzerland ${ }^{75}$. Similarly, Romania was unable to sell castor oil to Sweden due to the high price ${ }^{76}$. Although Romania was interested in selling beef and pork to Sweden, the price was once again an issue. Teodor Wölfer ${ }^{77}$, who owned a canning company in Sibiu named 'Scandia Română', came to Bucharest and tried to negotiate a reasonable price for the export of canned meat to Sweden ${ }^{78}$. These negotiations were unsuccessful; however, Wölfer persisted and searched for alternative ways to make the transport possible. He also had the idea to deliver canned meat to Sweden through `Finlandshjälpen ‘79. The

\footnotetext{
${ }^{74}$ Ibid.

${ }^{75}$ Ibid.

${ }^{76}$ Ibid.

${ }^{77}$ Teodor Wölfer, (sometimes written as Theodor Woelfer ) was the manager of 'Central Association of Peat Plants' in Sweden and the owner of 'Aktiebolaget Theodor Woelfer' in Malmö. A Jewish man of German origin, Wölfer emigrated to Sweden and helped other Jews to flee to Sweden during the Second World War. It was the reason why many partner companies from Germany cut ties with the Swedish businessman. Sven Norlund, 'Alkibiadeseller Akilles? Ariseringen i Sverige ochre aktioner na på denna', Historisk Tidskrift, 125:4, (2005): 19.

${ }^{78}$ Riksarkivet, UD, HP 2804, Vol. XI, November 1942 - January 1943, unpaged.

${ }^{79}$ Finlands hjälpen was a humanitarian association created in 1939 after the Soviet Union attacked Finland. The initiator was Maja Sandler, the wife of the Swedish Foreign Minister
} 
organization would purchase Romanian meat in order to assist Finnish refugees and share it with the Swedish authorities ${ }^{80}$.

One of the negotiations concluded with a positive result in 1942: 25 tractors by the Romanian Ministry of Agriculture from the Swedish company 'Bolinder-Munktell AB'. The payment was made via cash on delivery, and the company agreed to send the products in early 1943.

Although it encountered many obstacles, trade between Sweden and Romania had positive results in 1942 compared to the previous year. One explanation for this is that the prices for grain and oil increased throughout the year. Moreover, the authorities agreed to pay using free currency and only accepted compensatory exchanges in exceptional cases. Towards the end of the year, a report mentioned that Sweden imported products from Romania worth 51603000 Swedish crowns (103228 726 EUR). The numbers exceeded those of 1941 when the value of imports was only 28133000 Swedish crowns (60133074 EUR). Sweden also exported goods to Romania worth 3895000 Swedish crowns (8 325394 EUR) - more than Sweden sold in 1941 (581000 Swedish crowns representing today 1241862 EUR).

Despite being a neutral country that could avoid the disasters associated with war, Sweden nevertheless began to feel the effects of rising prices and inflation. Consequently, the Swedish government decided to adopt a new economic plan ${ }^{81}$ for 1943 to stop income increasing and limit purchasing power and price growth in a bid to avoid the collapse of the Swedish economy.

At the beginning of February 1943, the First Secretary Belfrage came to Bucharest to establish a list of products for import-export ${ }^{82}$. Among the products that Romania could export to Sweden during 1943 were: oil, asphalt, petroleum jelly, paraffin, acetone, grains, peas, nuts, eggs,

Rickard Sandler. This organization aimed to help both Finnish refugees in Sweden and those remaining in Finland. National encyklopedin, 'Finlands hjälpen', https://www.ne.se/uppslagsverk/encyklopedi/1\%C3\%A5ng/finlandshj\%C3\%A4lpen, accessed 10.08.2019.

${ }^{80}$ Riksarkivet, UD, HP 2804, vol. XI, November 1942 - January 1943, unpaged.

${ }^{81}$ AMAE, Fund 71/Suedia, vol. 22, 396-400.

${ }^{82}$ Riksarkivet, UD, HP 2804, vol. XII, February - Mars 1943, unpaged. 
intestines, pork, beef and poultry. The price was once again deemed too high $^{83}$, and the Swedish authorities only agreed to pay subventions to the import companies for eggs, meat, peas, and sunflower seeds ${ }^{84}$. From Sweden, Romania was interested in purchasing iron parts, steel pipes for locomotives and wagons, pneumatic tools and machine tools for CFR workshops, various telephony materials, welding machines, electric motors, motor pumps, diesel engines, furfural, paper and cipher machines, as well as agricultural machinery and equipment ${ }^{85}$.

Meanwhile, Germany promised to issue transport licenses for the products already bought by Sweden. However, in March 1943, cargo remained totalling 2525 tons of grain ${ }^{86}$ in Calafat, Oltenița, Giurgiu, Budapest, and Bratislava. Added to this were 868 tons of cereals bought by Sweden from the company 'Agroproduct SAR Bucharest', which were lost. The last information about the cargo indicated that the Germans confiscated the grain in Vienna. The Foreign Ministry from Stockholm attempted to investigate the merchandise; however, German authorities failed to provide any specific information about the shipment or delivery time $^{87}$.

Despite these inconveniences, Sweden was reluctant to lose contact with the Romanian market. Proof of this can be found in applications submitted to 'Handelskommissionen' by various companies in order to obtain export licenses to Romania for goods with a total value of 4917000 Swedish crowns (9 794309 EUR) ${ }^{88}$.

The main reason for the large number of applications was that the German policy of total war made trade between Sweden and Western countries impossible. Thus, some companies hoped to sign contracts with Romania. In one case, a paper producer asked Walldén to contact the Romanian authorities and place a paper order as the consul had business in

${ }^{83}$ Ibid.
${ }^{84}$ Ibid.
${ }^{85}$ Ibid.
${ }^{86}$ Ibid.
${ }^{87}$ Ibid.
${ }^{88}$ Ibid. 
Romania and was experienced in how things worked there ${ }^{89}$. Another case was represented by 'Aktiebolaget Radius', a company producing cooking machines and lighting fixtures running on kerosene. Due to the lack of this combustible, domestic sales had fallen dramatically. The company also had difficulty exporting its merchandise to Portugal, its primary customer, as the authorities were unable to issue transport licenses. Romania, therefore, came to be seen as a solution that could save the company from bankruptcy. In turn, Romania intended to purchase kerosene-fuelled lamps and stoves and was willing to pay for the order by cash on delivery to Swedish banks. 'AB Radius's ' manager was keen to utilize this opportunity and asked Belfrage to do everything possible for 'Industrikommissionen ` to approve the export contracts to Romania without complications ${ }^{90}$.

'Facit $A B$ ' faced a similar situation. Italy, the leading importer of their encryption devices, was unable to issue transport licenses, prompting 'Facit AB' to reorient and sell the products to Romania ${ }^{91}$. In the same way, 'Simon\&Sigm Brodaty', a company that produced glue and needed bones, encountered difficulty in the interwar period. Swedish glue factories bought raw materials from overseas or the Baltic neighbours. With the rupture of the transport routes, the factories' situation worsened, and Romania represented an option for saving the business. 'Simon\&Sigm Brodaty' ultimately ordered between $300-500$ tons of bones from Romania92.

In the spring of 1943, the Romanian delegation led by Mihai Răzmeriță and Romania's commercial attaché in Stockholm, Grigore Gheață, travelled to Sweden in order to finalize the negotiations started by Belfrage in Bucharest ${ }^{93}$. The Swedish Legation from Bucharest was skeptical about this visit, considering members of the delegation - employees of the National Economy Ministry - to be incompetent and interested only in visiting Stockholm for leisure ${ }^{94}$.

\footnotetext{
${ }^{89}$ Riksarkivet, UD, HP 2805, vol. XIII, April - May 1943, unpaged.

${ }^{90}$ Ibid.

${ }^{91}$ Riksarkivet, UD, HP 2805, vol. XV, August - November 1943, unpaged.

${ }^{92}$ Riksarkivet, UD, HP 2804, vol. XII, February - Mars 1943, unpaged.

${ }^{93}$ Ibid.

${ }^{94}$ Ibid.
} 
Nevertheless, this visit resulted in the signing of a trade treaty, which was to be implemented between May $5^{\text {th }}$ and December $31^{\text {st }}, 1943^{95}$. The trade agreement was of particular importance, being the first of its kind established between the two countries. The contract had 12 articles setting out each state's obligations, goods, and estimated quantities to be exported, as well as payment methods. Moreover, the document also contained an annex in which 'Handelskommission ' reserved the right to control all Romanian companies' offers sent before negotiations began. For their part, Swedish companies would be required to present complete documentation in order to obtain transport permits. This documentation should include details such as the type of product, quantity, value, payment conditions, in addition to information on the company that made the offer. The Swedish authorities received this agreement with great enthusiasm. The Minister of Foreign Affairs Christian Günther expressed his satisfaction in a telegram he sent to Mihai Antonescu ${ }^{96}$.

This trade treaty brought immediate positive effects for Sweden. Since June, the Romanian authorities had decided to reduce the customs tariffs by $75 \%$ for agricultural machinery purchased from Sweden ${ }^{97}$. Moreover, the Swedish export to Romania amounted to 9 million Swedish crowns (17 927350 EUR) ${ }^{98}$.

Romania, at the time operating somewhat rudimentary industrial and agricultural methods without modern machines or tools, was interested in importing Swedish technology in large quantities. However, 'Handelskommissionen 'assessed the Romanians' demand and compared it with internal needs. The conclusion was that there were goods ${ }^{99}$ for which the Swedish authorities could not issue transport licenses. Even so, 'Handelskommissionen' approved the requests for products worth 954554 Swedish crowns (1901403 EUR) in only one week ${ }^{100}$. Unfortunately for

\footnotetext{
${ }^{95}$ Riksarkivet, UD, HP 2805, vol. XIII, April - May 1943, unpaged.

${ }^{96}$ Riksarkivet, UD, HP 2805, vol. XIV, May - July 1943, unpaged.

${ }^{97}$ Ibid.

${ }^{98}$ Riksarkivet, UD, HP 2805, vol. XV, August - November 1943, unpaged.

99 These included emulsion pumps, motorized draisines, diesel locomotives and electrocardiographs.

${ }^{100}$ Riksarkivet, UD, HP 2805, vol. XV, August - November 1943, unpaged.
} 
'Facit $\mathrm{AB}$ ', Swedish authorities rejected its application. The managers of this company contacted the Swedish Ministry of Foreign Affairs and asked them to review the decision. The situation was critical for 'Facit $A B$ '; the internal market absorbed only $20 \%$ of production, which failed to cover salaries for all 500 employees ${ }^{101}$. 'Garvämnes AB Weibull', meanwhile, was not optimistic about the tannery industry's future and urged authorities to withdraw their rejection and approve the export of 100 tons of conifer bark extract (a product used in leather processing) to Romania ${ }^{102}$. Another company that considered Romania one of the few countries to which it could sell was 'Husqvarna Vapenfabriks Aktiebolag'. Therefore, the company requested that Swedish officials approve export licenses for sewing machines, bicycles, irons, and gas stoves ${ }^{103}$.

One of 'Industrikommissionen" s reports from 1943 revealed that Romania was the leading exporter of liquid lubricants to Sweden, covering $61.66 \%$ of the total quantity purchased by the Swedish state ${ }^{104}$. Regarding exports to Romania, Sweden issued transport licenses for products worth 1460000 Swedish crowns (2 920643 EUR) by the beginning of July $1944^{105}$.

Nevertheless, there was a visible decline in trade between the two countries in the first half of 1944. One clear explanation for this phenomenon would be Romania's peace negotiations with the Soviet Union, and the political instability that marked the country in that period had consequences for economic development. Moreover, Germany was only intermittently allowing the transit of oil tanks to Sweden.

Between 1940 and 1944, the import/export balance between Sweden and Romania fell in Romania's favour. Imports from Sweden represented only $0.3 \%$ of the total imports of the Romanian state, while exports to Sweden represented $2.2 \%$ of the whole quantity exported by the Romanians ${ }^{106}$.

\footnotetext{
${ }^{101}$ Ibid.

102Riksarkivet, UD, HP 2805, Vol. XVI, December 1943-1944, unpaged.

${ }^{103}$ Ibid.

${ }^{104}$ Ibid.

${ }^{105}$ Ibid.

106 Victor Axenciuc, Evoluția economică a României. Cercetări statistico-istorice 1859-1947, Vol III, (București: Editura Academiei Române, 2000), 531-533. According to Axenciuc, the countries
} 
The dynamics of the Romanian economy changed markedly following August 23 $3^{\text {rd }}$, when King Michael I succeeded in deposing Antonescu's regime, agreed to conditions set by the Allies in the armistice, and declared war on Germany. Germany cut trade ties between Romania and the Axis and completely blocked the transit of goods to and from Sweden. In addition to this, Germany blocked the transport of 509 barrels of oil that Romania had sold to Sweden in August $1944^{107}$.

Simultaneously, Romania was obliged to accept the policies and conditions of their new allies, which meant an interruption of trade connections with Switzerland due to the Soviet Union having broken political relations with them. Moreover, like other Balkan states under Soviet occupation, Romania was unable to trade with the USA despite being ostensibly allies ${ }^{108}$. Swedish companies, however, were not deterred by this new reality; instead, they perceived new business opportunities. 'AB ASTRA', for example, delivered 11.5 tons of Sulfathiazole to Romania (two tones were sent to the Soviet Union) and were planning to export Dichlorodiphenyltrichloroethane (DDT) at the beginning of $1945^{109}$. Due to the typhus epidemic that hit Romania and the Romanian army, the Soviet ambassador in Stockholm, Alexandra Kollontai, asked 'AB ASTRA' to fly in DDT to Romania immediately. The Soviet Union provided the necessary aircraft for transportation ${ }^{110}$.

At the beginning of 1945, the Soviet Union blocked the SwedishRomanian trade. This time, the Soviets refused to let the freight trains pass from Sweden to Romania ${ }^{111}$. Both countries attempted to convince Moscow to reopen the transit. In June 1945, the Soviets agreed to issue transport licenses for the products that Romania had already purchased ${ }^{112}$. The decision was insufficient for the Romanian economy. As a reaction to this,

that imported the most from Romania during the aforementioned period were Germany $(56,2 \%)$, Italy $(11,6 \%)$, and England $(6,7 \%)$ while Romania imported most of its products from Germany (64,7\%), Italy (11,3\%) and Czechoslovakia (7,8\%).

${ }^{107}$ Riksarkivet, UD, HP 2805, vol. XVII, 1945 - November 1946, unpaged.

${ }^{108}$ Riksarkivet, UD, HP 2805, vol. XVI, December 1943-1944, unpaged.

${ }^{109}$ Ibid.

${ }^{110}$ Riksarkivet, UD, HP 2805, vol. XVII, 1945 - November 1946, unpaged.

${ }^{111}$ Ibid.

${ }^{112}$ Ibid. 
authorities from Bucharest appointed a new economic attaché in Stockholm, Titus Cristureanu ${ }^{113}$, hoping that he could make possible the resumption of trade between the two countries ${ }^{114}$.

Romania needed technology to sustain its economy; products that, previous to August 23 ${ }^{\text {rd }}$ 1944, had been purchased from Germany. Thus, Sweden became the only country from which the Romanians could purchase these goods.

Although the Soviet Union stated that it was not interested in monopolizing the Romanian foreign trade, in practice, Russia went to considerable lengths to prevent the conclusion of new agreements between Stockholm and Bucharest - the pretext being that the Soviet Union could deliver the same products as Sweden ${ }^{115}$. Moscow authorities issued transport licenses only for Swedish products that the Soviets themselves needed. In addition to this, the Soviet Union blocked all telegrams sent by the Romanian authorities to Stockholm.

The end of the Second World War found Romania economically isolated. The routes that linked it to Northern Europe were not viable. The most efficient route, Danube-Elba-Hamburg, disappeared when Romania realigned against Germany. Bombing destroyed the railway network, and Poland's air route, now Soviet airspace, became inaccessible. The last transportation option, Constanța harbor, suffered damages during the bombing and was under Soviet Union control. Under these circumstances, the Swedish Legation in Bucharest had significant doubts about the possibility that the two states' economic relations would improve shortly.

\footnotetext{
${ }^{113}$ Titus Cristureanu was a Romanian economist and diplomat. He became the first attaché of the Kingdom of Romania in Moscow and Istanbul. After being appointed economic attaché in Stockholm, Cristureanu also dealt with Romania's economic interests in Finland, Norway and Denmark. Mihai Korka, ' Titus Cristureanu - Leading Figure of the Romanian International Business and Economics Higher Education Tradition', Amfiteatru Economic, 22 (51), 2019: 480-488.

${ }^{114}$ Riksarkivet, UD, HP 2805, vol. XVII, 1945 - November 1946, unpaged.

${ }^{115}$ Ibid.
} 
The situation of Swedish companies in Romania during the Second World War

At the beginning of the Second World War, several Swedish companies had their own commercial agencies on Romanian ground: 'Svenska Kullagerfabriken`; 'Elektrolux'; 'LM Ericsson`; 'Elektro-Invest', which owned a power plant; and 'STAB', that owned two match factories.

The companies above faced several difficulties caused by the lack of an economic treaty to regulate trade. This, in turn, triggered a cascade of problems that complicated the existence of Swedish businesses in Romania, prompting some to close their branches.

One Swedish firm with a history on the Romanian market, which faced a number of difficulties, was 'Helsingborgs Gummifabriks AB'. It had opened a sales office in Romania in 1913 and was beginning to prove profitable. The company was one of the most prominent Swedish exporters in Romania during the interwar period, as shown in the table below.

Table 4: Gummifabriks export to Romania during 1923-1938

\begin{tabular}{|l|l|l|l|l|}
\hline Year & $\begin{array}{l}\text { Sweden's export } \\
\text { to Romania (Sek) }\end{array}$ & $\begin{array}{c}\text { Value in } \\
\text { EUR } \\
2019\end{array}$ & $\begin{array}{l}\text { Gummifabriks export } \\
\text { to Romania (Sek) }\end{array}$ & $\begin{array}{c}\text { Value in } \\
\text { EUR } \\
2019\end{array}$ \\
\hline 1923 & 605510 & 1628972 & 472579 & 1271354 \\
\hline 1924 & 581598 & 1564643 & 212670 & 572135 \\
\hline 1925 & 1665181 & 4403821 & 968857 & 2562288 \\
\hline 1926 & 1460796 & 3998848 & 710072 & 1943783 \\
\hline 1927 & 2695743 & 7466778 & 1826941 & 5060335 \\
\hline 1928 & 3708993 & 10153163 & 2704816 & 7404284 \\
\hline 1929 & 4808024 & 13396730 & 1560892 & 4349157 \\
\hline 1930 & 4330454 & 12512955 & 733868 & 2120530 \\
\hline 1931 & 1696024 & 5056777 & 607224 & 1810468 \\
\hline 1932 & 2291527 & 6920457 & 762571 & 2302979 \\
\hline 1933 & 2099102 & 6507259 & 403230 & 1250021 \\
\hline 1934 & 2861948 & 8813728 & 633172 & 1949933 \\
\hline 1935 & 1940271 & 5859657 & 281041 & 848749 \\
\hline 1936 & 1296610 & 3865905 & 100241 & 298873 \\
\hline
\end{tabular}




\begin{tabular}{|l|l|l|l|l|}
\hline 1937 & 3639000 & 10514982 & 375193 & 1084130 \\
\hline 1938 & 3500000 & 9929459 & 207459 & 588559 \\
\hline
\end{tabular}

Source: Riksarkivet, UD, HP 2802, Rumänien, Vol. VI, May-1932 Mars-1941.

Despite being a loyal customer of the Romanian state, the company suffered as a result of the Bucharest authorities' decision to limit imports from Sweden. The management of Gummifabriks AB pointed out that the factory did not obtain any export licenses to Romania, although negotiations were underway for the conclusion of a trade agreement ${ }^{116}$.

'ALKA Aluminiumkapslar' ${ }^{117}$ was another Swedish company with experience in the Romanian market that faced challenges. 'ALKA' had been operating in Romania since 1933; however, during the war, faced difficulties recovering its debts. The Romanian partners produced and sold aluminium caps with 'ALKA' equipment but did not pay for manufacturing licenses. In a letter sent to the Swedish Foreign Ministry, 'ALKA' requested assistance in order to recover the money ${ }^{118}$. The absence of a clearing-based agreement to complete the 1922 trade treaty made this almost impossible.

Due to the political instability and uncertainty that characterized Romania at that time, the company 'Trätälja'119 requested payment in advance in order to deliver paper bags purchased by the Romanian company 'Textilunion SAR' for the 'Autonomous House of Monopolies'. Although Romania attempted to get 'Trätälja's representatives to accept payment of the products on arrival in the country, the company's leadership did not accept this option ${ }^{120}$. Consequently, 'Trätälja' lost the deal in favour of German businessmen, who accepted the conditions

\footnotetext{
${ }^{116}$ Riksarkivet, UD, HP 2802, Rumänien, vol. VI, May 1932 - Mars 1941, unpaged.

117 ALKA Aluminiumkapslar was a Swedish manufacturer from Linköping that produced aluminum caps and capsules. August Hessler, ed., Svenskindustrikalender, (Stockholm: Sveriges industriförbund, 1947), 9.

${ }^{118}$ Riksarkivet, UD, HP 2803, Rumänien, vol. VII, April - December 1941, unpaged.

${ }^{119}$ Trätälja is a Swedish company founded 1906 in Gothenburg that exports timber and wood products. The company took its name from the Viking king Olof Trätälja. Historians claim that he was a mythological figure as opposed to a real person.

${ }^{120}$ Riksarkivet, UD, HP 2803, Rumänien, vol. VII, April - December 1941, unpaged.
} 
imposed by the Bucharest authorities ${ }^{121}$.

Romania would go on to lose another Swedish business when 'Sandvikens Jernverks $A B{ }^{\prime 22}$ decided to close the sawmill built in Bucharest in 1935 due to not being able to withdraw money on the investments ${ }^{123}$.

Following 'Sandvikens Jernverks $\mathrm{AB}$ ', another Swedish firm intended to decrease activity in Romani: 'Electro-Invest $A B{ }^{` 24}$, which in October 1931 leased the production and distribution of electricity for 25 years from the administration of Brasov city ${ }^{125}$. Sweden requested the Romanian state or municipality of Brasov to buy back the concession. Mihai Antonescu refused, explaining that Romania was in great need of the Swedish capital for internal development ${ }^{126}$.

The Swedish Road Company, 'Svenska Vägaktiebolaget', on the other hand, extended its 1931 contract signed with Romania until 1943. Sweden intended to complete the work on national road No. 1 BucharestBraşov-Sibiu-Alba-Iulia-Turda-frontier as well as the Ploiești-Mizil road and the exits from Brașov ${ }^{127}$.

The financial interests that 'C. A Wallenborg\&Son ' had in Romania led to the opening of a subsidiary called 'Wallenborg Romana SA'128. Through this Romanian subsidiary, the Swedish company concluded business with various firms amounting to approximately 200000 Swedish crowns (398386 EUR) per month - a substantial amount, especially considering that Sweden's export to Romania was not significant at that time. The products intended for export to Romania were mostly separators,

\footnotetext{
${ }^{121}$ Ibid.

${ }^{122}$ Sandvikens Jernverks AB is a Swedish company headquartered in Stockholm, founded in 1862 It produces iron cutting machines and mining equipment. Westrin, Nordisk familjebok, (Stockholm: Nordisk Familjebok Tryckeri, 1916), 679.

${ }^{123}$ Riksarkivet, UD, H 2681, Rumänien 1921- , unpaged.

${ }^{124}$ Aktiebolaget Electro-Invest was founded by the banker and businessman Marcus Wallenberg in partnership with the 'ASEA ' director, Sigfrid Edström. The original purpose of this company was to make concessions and build power plants in Eastern Europe.

${ }^{125}$ Riksarkivet, UD, H 2707, Klagomål och krav i andra kommersiella frågor, Rumänien, unpaged.

${ }^{126}$ Riksarkivet, UD, HP 2805, vol. XIV, May - July 1943, unpaged.

${ }^{127}$ AMAE, Fund 71, Suedia, vol. 5, 82.

${ }^{128}$ Riksarkivet, UD, HP 2804, vol. XII, February - Mars 1943, unpaged.
} 
sewing machines, engines, coolers and ovens. Even Mihai Antonescu became interested in Swedish activity on the Romanian market and promised support. One problem, however, was that Romania was unable to purchase the goods they intended to import with foreign currency.

At the time of Romania's alliance with the Soviet Union on August $23^{\text {rd }}, 1944$, six large Swedish enterprises were operating in Romania ${ }^{129}$. The company with the most interests and most profitable business was 'Svenska Tändsticks AB' (STAB). As a result of the loan granted to Romania in 1929, 'STAB' obtained a total monopoly on the matchstick industry for 30 years. This monopoly was exercised through the subsidiary 'Chibriturile SAR Bucureşti', under the full management of 'STAB', and the company 'Brichetele SR Bucureşti', which 'STAB' owned together with the Romanian State.

'AB Electro-Invest' was another established company in Romania at the time, able to lease and maintain control over electricity production in three cities following a contract signed with Romanian authorities. The company owned half of the shares in 'Electrica Brașov SA' in Brașov, 69\% of shares in 'Societatea de Electricitate Râmnicu-Vâlcea SA' in RâmnicuVâlcea, and $72 \%$ of shares in 'Societatea de 'Electricitate Vaslui SA '130. in Vaslui. Moreover, the company had two further subsidiaries: 'ElectroInvest SAR', which handled financing and services, and 'ASEA', responsible for sales.

Meanwhile, 'LM Ericsson' delivered equipment to Romania worth 18900000 lei (354 139 EUR), according to the quarterly balance of March $31^{\text {st }}, 1944^{131}$. The company did not have an office in Romania, however, exercised its interests through the 'Ericsson SAR' subsidiary, headquartered in Bucharest.

Another Swedish business in Romania was 'AB Svenska Kullagerfabriken '(SKF), which owned one boutique in Bucharest and two warehouses: one in Ghimpati, the other near Timişoara. In addition, 'Svenska Väg AB Stockholm' held equipment worth 250000 Swedish

\footnotetext{
${ }^{129}$ Riksarkivet, UD, HP 2805, Vol. XVI, December - 1943 - 1944, unpaged. ${ }^{130}$ Ibid.

${ }^{131}$ Ibid.
} 
crowns (500 110 EUR) and was the leading road builder in Romania. Finally, 'AB Theodor Woelfer Malmö' owned half the shares of 'Scandia Romanian SA din Sibiu', a large canning producer.

\section{Conclusions}

When analysing economic and trade relations between Sweden and Romania, it becomes clear that these relations represented a reoccurring concern for the two countries.

Despite playing a secondary role in the early twentieth century, Swedish-Romanian became more important during the interwar period, as the Romanian government encouraged foreign capital investment in sectors such as industry and agriculture.

The Second World War influenced trade between Sweden and Romania together with various geographical and political factors, not to mention the attitude of the Great Powers. Under these conditions, it proved challenging to maintain economic relations at an average level. Moreover, there were large fluctuations in the import/export balance in Romania's favor, despite German authorities blocking Swedish-Romanian trade entirely for several months.

Although Sweden succeeded in remaining neutral, it was not immune to economic deprivation. Before the Second World War, the Swedish trade market did not include Romania, and vice versa. The outbreak of war and the limitation of alternatives brought the two countries closer together. The commercial routes linking Sweden to the Americas and East Asia were closed, and Romania became, for many Swedish companies, a potential solution to help them survive the crises. Romania, meanwhile, went to great lengths in order to prevent the national economy from falling under the Axis countries' total monopoly. Eventually, however, trade between Sweden and Romania declined due to Romanian bureaucracy, the absence of an economic treaty regulating the Romanian-Swedish trade, and the lack of clearing.

Romania was a predominantly rural country that was in great need of technology to modernize agriculture and develop the industry. The primary products imported from Sweden were, therefore, agricultural 
machinery and tools, engines, locomotives, equipment used in telecommunications and furfural. Romania was also interested in importing Swedish paper and fish. Conversely, Sweden mainly imported grains, feed, and petroleum products. Established Swedish businesses chose to open offices in Romania for better collaboration with the Romanian partners, bolstering Swedish-Romanian economic relations. 'ASEA', 'AB Elektro-Invest', 'LM Ericsson', 'STAB', and 'Svenska Vägaktiebolaget' were among companies visible on the Romanian market.

The role of Germany in the evolution of economic relations between Bucharest and Stockholm cannot be ignored, particularly at the time of its alliance with Romania. Germany took issue with Romania selling grain and petroleum products to countries outside of the Axis powers. Moreover, Germany controlled the main road that linked Northern and Southern Europe and went to considerable lengths in order to impede trade between Sweden and Romania. These methods involved refusing to issue transport licenses, blocking the transit of tankers, trains, and barges, as well as confiscating goods. These practices resulted in extended delays, damaged goods and the loss of business partners.

Swedish-Romanian trade encountered similar practices following August 23rd, 1944, when Romania fell under the Soviet sphere of influence and would go on to face further isolation and limited import/export options at the hands of the Soviet Union.

\section{References:}

\section{A. Archives:}

Arhivele diplomatice ale MinisteruluiAfacerilorExterne al României [The Diplomatic Archives of the Romanian Foreign Ministry], București: Folder 71/Suedia, 1928-1944, vol. 5, 6, 21, 22.

Folder 64/Suedia, vol 4.

SverigesRiksarkivet, Utrikesdepartementet, [The National Archive of Sweden, Ministry of Foreign Affairs], Stockholm:

H 610 Tulltariffer, exporttullar 1932-1951, Vol. II.

H 867 Rumänien 1920-1950, vol I. 
H 1264.

H 1277, Rumänien.

H 2681, Rumänien 1921-.

H 2707, Klagomål och krav i andra kommersiella frågor, Rumänien.

HP 2802, Rumänien, vol. VI, May 1932 - Mars 1941.

HP 2803, Rumänien, vol. VII, April-Decembrie 1941, vol. VIII, January May 1942, vol. IX June - August 1942.

HP 2804, vol. X, September - November 1942, Vol. XI, November 1942 January 1943, vol. XII, February - Mars 1943.

HP 2805, Rumänien, vol. XIII, April - May 1943, vol. XIV, May - July 1943, vol. XV, August - November 1943, Vol. XVI, December 1943-1944, vol. XVII, 1945 - November 1946.

\section{B. Newspapers:}

Aftonbladet, July 9, 1912

\section{Books and articles:}

Axenciuc, Victor, Evoluția economică a României. Cercetări statistico-istorice 1859-1947, Vol III, București: Editura Academiei Române, 2000, 531533.

Buzatu, Gheorghe, O istorie a petrolului românesc, Iași: Casa Editorială Demiurg, 2009.

Ciumara, Mircea, Ciutacu, Constantin, Inflația în România. Modelarea fenomenului inflaționist București: Editura Expert, 2004.

Klarin E., 'Svenska tändstickbolaget och Kreuger-koncernen' in Svenska Dagbladets Årsbok, ed. E. Rudberg, E. Hellblom, Stockholm: Åhlén \& Åkerlunds Boktryckery, 1928.

Korka, Mihai,' Titus Cristureanu - Leading Figure of the Romanian International Business and Economics Higher Education Tradition', Amfiteatru Economic, 22 (51), 2019.

Norlund, Sven, 'AlkibiadesellerAkilles? Ariseringen i Sverigeochreaktionernapådenna',Historisk Tidskrift, 125:4, 2005.

Popescu, Oana, România și Danemarca în prima jumătate a secolului XX, Târgoviște: Editura Cetatea de Scaun, 2010. 


\section{Encyclopedias}

Hessler, August ed., Svensk industrikalender, Stockholm: Sveriges industriförbund, 1947.

Westrin, Theodor, ed., Nordisk familjebok, Stockholm: Nordisk Familjebok Tryckeri, 1916, 1922.

\section{E. Web postings}

Bohlin, Jan, From appreciation to depreciation - the exchange rates of the Swedish krona 1913-2008, https://www.riksbank.se/en-gb/about-theriksbank/the-tasks-of-the-riksbank/research/historical-monetarystatistics-of-sweden/volume-i-exchange-rates-prices-and-wages1277-2008/, accessed 17.10.2020

Nationalencyklopedin, 'AB Separator', https://www.ne.se/uppslagsverk/encyklopedi/1\%C3\%A5ng/abseparator, accessed 08.08.2019.

Nationalencyklopedin, 'Finlandshjälpen', https://www.ne.se/uppslagsverk/encyklopedi/1\%C3\%A5ng/finlands hj\%C3\%A4lpen, accessed 10.08.2019.

Riksarkivet, 'AB SvenskaKullagerfabriken (1907-)', https://sok.riksarkivet.se/agent/0WJTCmDHl4YSYuOIfuAJY0, accessed 08.08. 2019.

Romanian National Bank (BNR), https://www.cursbnr.ro/convertorvalutar, accessed 10.10.2020.

Rune Kjellander, 'Berndt A Hjorth', https://sok.riksarkivet.se/sbl/Presentation.aspx?id=13649, accessed 08.08.2019.

Statistiska centralbyråns http://www.sverigeisiffror.scb.se/hitta-statistik/sverige-i siffror/prisomraknaren/, accessed 15.10.2020.

Swedish National Bank (Riksbanken) https://www.riksbank.se/sv/statistik/sok-rantor valutakurser/manadsgenomsnitt valutakurser $/ \mathrm{y}=2019 \& \mathrm{~m}=12 \& \mathrm{~s}=$ Comma\&f=m.), accessed 15.10.2020 